\title{
INFORMAÇÕES DADAS AO PACIENTE CONTAGIOSO: ESTUDO COMPARA. TIVO ENTRE OPINIÃO DE ENFERMEIRAS E PACIENTES
}

\author{
NOTA PRÉVIA
}

Adélia Maya Chida*

CHIDA, A. M. Informações dadas ao paciente contagioso: estudo comparativo entre opinião de enfermeiras e pacientes. Nota prévia. Rev. Esc. Enf. USP, São Paulo, 15(3):319-320, 1981.

Adquirir doença contagiosa e ser internado em unidade de isolamento constitui um dos fatos mais traumatizantes para o paciente, fazendo com que ele perceba a sua situação de forma sempre mais negativa do que a realidade. 0 ambiente de isolamento é totalmente desconhecido para ele; não havendo orientação adequada sobre esse ambiente e sobre o caráter contagioso da moléstia, instala-se uma desorganização no conjunto de cognições e percepções que o indivíduo tem sobre si mesmo como uma pessoa ativa, dentro do contexto do grupo social a que pertence. Por esse motivo, as informações devem ir de encontro às suas reais necessidades.

Na prática, porém, observa-se com freqüência pacientes em conflito, gerado essencialmente pela discordância entre eles e as enfermeiras, no que tange às informações consideradas prioritárias.

Diante do exposto, a autora se propõe a:

- averiguar se o nível de importância atribuído pelos pacientes contagiosos, recém-admitidos em Unidades de Isolamento, às informações relativas à doença, tratamento, ambiente de isolamento, cuidados pós-alta, equipe assistencial e rotinas do hospital, difere daquele referido pelas enfermeiras;

- comparar os graus de importância atribuídos, pelos pacientes e enfermeiras, às informações supracitadas;

- verificar se os graus de importância atribuídos pelos pacientes, a essas informações, estão relacionados com fatores bio-sociais: idade, sexo e escolaridade.

A coleta de dados está sendo feita, tendo como instrumento dois formulários destinados à entrevista com pacientes e enfermeiras, respectivamente.

CHIDA, A. M. Informations given to contagious patient: comparative study between nurses and patients' opinion. Previous note. Rev. Esc. Enf. USP, São Paulo, 15(3):319-320, 1981.

Contagious patient is often dealing with feelings of: loss, anxiety, guilt and being deprived of his liberty. Those phenomena denote how stressing for him the unknown isolation unit surroundings are. \footnotetext{
* Auxiliar de Ensino do Departamento de Entermagem Médico.Círúrgica da EEUSP, disciplina Enfer-
margem em Doenças Transmissíveis.
} 
The crisis tends to increase if the orientations about the nature of infectious disease and the patient's new system of life during hospitalization were not adequately explained by nurses or other health professional who to be care of him.

Having observed that frequent problematic, the auhor proposes:

- to investigate if the level of importance attributed by new hospitalized contagious patients, confined in isolation units, to informations related to disease and its treatment, isolation ambient, after discharging cares, health group and hospital routines, differs from that ascribed by nurses;

- to compare the degrees of importance attributed, by those patients and nurses, to over-mentioned informations;

- to verify if the degrees of importance ascribed by patients to those informations are connected through social-biological factors as age, sex and education.

Data collection is being done by interview throughout two questionnaires respectively assigned to patients and nurses. 